\title{
Audit Committee and Value Relevance of Accounting Information of Listed Hotels and Travels in Sri Lanka
}

\author{
Saseela Balagobei \\ Senior Lecturer, Department of Financial Management, University of Jaffna, Sri Lanka \\ E-mail: saseelas@yahoo.com
}

Received: July 3, 2017 Accepted: August 2, 2017 Published: December 1, 2017

doi:10.5296/ajfa.v9i2.12290 URL: https://doi.org/10.5296/ajfa.v9i2.12290

\begin{abstract}
The audit committee (AC) is the potential mechanism that reduces the agency problems in organizations and investigating this mechanism separate from alternate corporate governance mechanisms may have led to different results in the literature. The aim of this study is to examine the impact of audit committee on value relevance of accounting information of listed hotels and travels in Sri Lanka. Value relevance of accounting information is measured by earning per share (EPS) and book value per share (BVPS) while Audit committee consists of $\mathrm{AC}$ size, $\mathrm{AC}$ independence, $\mathrm{AC}$ experts and $\mathrm{AC}$ meetings. The sample consists of 15 hotels and travels listed in Colombo Stock Exchange. In this study, data was collected from secondary sources and hypotheses are examined by using Pearson's correlation and regression analysis. The results reveal that audit committee attributes such as AC size, AC experts and AC meetings have a significant impact on book value per share of listed hotels and travels in Sri Lanka. Further only AC experts influence earnings per share. AC independence is not found to have a significant impact on the value relevance of accounting information. The findings could be useful to regulators in other jurisdiction who are looking at ways to enhance the effectiveness of audit committee, overall firm governance.
\end{abstract}

Keywords: Audit Committee, Value relevance of Accounting information, Audit committee size, Audit committee experts, Audit committee meetings

JEL: G3 


\section{Introduction}

Increasing the investment in capital market leads to improve strength of the capital market and development of economy. Investors rely on accounting information in their pricing of shares and firms which provide good quality information have thus an advantage in a lower cost of capital. Investors in developed counties are keen on the accounting information of the intended investing companies. So that, investigation of the audit committee with value relevance of accounting information is an important matter for the developing countries, like Sri Lanka.

The audit committee is one of the key elements in the corporate governance structure that helps control and monitor management (Ruzaidah and Takiah, 2004). The committee plays a vital role in monitoring the organization's operation and internal control system with the purpose of protecting the interest of the shareholders. The audit committee (AC) contributes to the development of the strategic plan of the company and is expected to provide input and recommendations to the board with regard to any financial or operational matters. Hence, it is recognized that an effective audit committee would focus on improving the company performance and competitiveness, particularly in a changing business environment which is beyond the control of the company (Charan, 1998; Craven and Wallace, 2001). An effective audit committee is expected to focus on the optimization of shareholders' wealth and prevent the maximization of personal interests by the top management (Wathne and Heide, 2000).

The primary role of the audit committee is to oversee the firm's financial reporting process, the review of financial reports, internal accounting controls, the audit process and, more recently, its risk management practices (Klein, 2002). The main focus of audit committees is to strengthen transparency, promote effective enforcement, and identify needs for training and education for directors and key players of an organization. In March 2013, the Securities and Exchange Commission of Sri Lanka and the Institute of Chartered Accountants of Sri Lanka developed the Code of the Best Practices of Corporate Governance, which provides guidelines on the formation of the audit committee, particularly with respect to size, independence, duties and responsibilities of members to ensure good practices of corporate governance. Detailed guidance on the scope and functions of the audit committee can be found in the Code of Best Practice on Audit Committees issued by the Institute of Chartered Accountants of Sri Lanka in 2002.

Porter and Gendall (1993) discussed audit committee development in Canada, the United States, the United Kingdom, Australia and New Zealand, identifying unexpected corporate failure and corporate malpractice as the primary stimuli to their development. Teoh and Lim (1996) also explained the establishment of audit committees in Malaysia as a response to corporate scandals.

Value relevance is the ability of accounting numbers to explain market price per share. Beisland (2009) describes value relevance as the capability of financial statement information to tap and summarize firm value. Kalbers and Fogarty (1993) suggested that audit committee members with expertsise in accounting and finance, enhances the effectiveness of the audit committee. Furthermore, it is also established that audit committee expertsise enhances the 
quality of financial reporting.

The hotel and travels industry is a decisive player in promoting tourism industry in Sri Lanka. Incubating market centrism has received particular attention in the modern business world as a mode of reaping higher business performances. According to the Central Bank of Sri Lanka (2014), the contribution of hotels and restaurants to the country's Gross Domestic Product is increased by $11.5 \%$. The accommodation facilities prevailing in the hotel industry in Sri Lanka are dominated by tourist hotels.

According to Sri Lanka's Tourism Authority, the country has a target of 2.2 million visitors for 2016, which would be a 26\% growth compared with 2015. The Tourism Authority's statistics show that Sri Lanka has welcomed 1.7 million visitors as of October, a 14.6\% increase compared with the same time period last year. Through the efforts to help Sri Lanka's tourism industry grow, the country's hotel demand has increased $3.5 \%$ based on October 2016 year-to-date data. Supply, however, has also increased $(+4.2 \%)$, with around 900 new rooms added to the market in the first ten months of the year. Therefore the objective of this study is to investigate the impact of audit committee on value relevance of accounting information of listed hotels and travels in Sri Lanka during the period of 2012 to 2016.

\section{Problem of the Statement}

Although many Sri Lanka listed companies had appointed an audit committee as in many other Asian countries (OECD White Paper 2003), a transparent procedure was absent in the determination of directors' remuneration in them (Senaratne and Gunaratne, 2007). The prominence of audit committees in Sri Lankan companies may have been associated with the dominance of accounting professionals in the boards of these companies and the developed accounting profession in Sri Lanka (Senaratne, 2007). However, the appointment of a nomination committee to oversee board appointments including succession planning and performance evaluation of directors is not yet mandatory for listed companies except for licensed commercial banks for which it is mandatory under the Central Bank Direction. It is questionable why the Listing Rules have not made the establishment of a nomination committee mandatory. A proper and transparent procedure on board appointments is a key to have an effective board as the roles and responsibilities of directors underpin the task of corporate governance. The lack of transparency in the board appointments has also been found as a negative corporate governance feature in many Sri Lankan listed companies (Senaratne and Gunaratne, 2007). Hence, this area needs special attention.

To address this issue the study was undertaken to explore the answer to the following research question: To what extent audit committee impacts on value relevance of accounting information?

\section{Literature Review and Hypotheses Development}

According to the Code of best practice on corporate governance (2013) issued jointly by the Securities and Exchange Commission of Sri Lanka and the Institute of Chartered Accountants of Sri Lanka, the audit Committee should be comprised of a minimum of two independent 
non-executive directors or exclusively by non-executive directors, a majority of whom should be independent, whichever is higher. The guideline further requires that the chairman of the committee should be a non- executive director, appointed by the board.

An extensive body of market-based accounting research (MBAR) tests for relevance of accounting information by investigating the association of such information with equity prices (Ball and Brown, 1968). MBAR research relied on earnings, or a component of earnings, as explanatory variables for security returns. This is logical, because the valuation theory has long posited a relationship between earnings and the value of common stock (Miller and Modigliani, 1961; Graham et al.,1962). Subsequent analytical work by Ohlson (1995) includes another valuation construct, book value of equity, along with earnings in tests of market pricing of accounting information.

An effective corporate governance system ensures the provision of credible accounting information to financial statement user groups by constraining opportunistic earnings management by managers. Corporate governance also helps investors by aligning the interest of managers with the interests of shareholders and enhancing the reliability of financial information and the integrity of the financial reporting process (Watts and Zimmerman, 1986).

Klein (2002) investigates the relationship between board independence, board size and audit quality and shows that audit quality is negatively related with board book value per share and abnormal accruals. Davison al (2005) investigates the relationship between audit comity, non-executive director on the board and earning management in Australia and shows that audit comity and non executive director has negative relationship with earning management. Outside director were financial experts who efficiently monitor the activity of audit committee of the firm. As financial expert, director was able to monitor and detect any kind of manipulation in financial reports (Abbott et al., 2002).

DeZoorts and Salterio (2001) and Carcello and Neal (2003) found that there was negative association between financial expertise and auditor dismissal in cases of disputes between auditor and management. Similarly, Abbott, Park, and Parker (2000) suggested that there was negative relationship between financial expertise and financial fraud. Further, according to Felo, Krishnamurthy, and Soloeri (2003), there is positive association between financial expertise and financial reporting quality.

Based on the above discussion, the following hypotheses are developed:

$\mathrm{H}_{1}$ : Audit committee size significantly influences value relevance of accounting information.

$\mathrm{H}_{2}$ : Audit committee independence significantly influences value relevance of accounting information.

$\mathrm{H}_{3}$ : Audit committee experts significantly influences value relevance of accounting information.

$\mathrm{H}_{4}$ : Audit committee meetings significantly influence value relevance of accounting information. 


\section{Research Methodology}

The research methodology focuses on the research process, kind of tools and procedures to be used. This study tends to analyze the impact of audit committee on value relevance of accounting information.

\subsection{Sample and Data}

The population of the study comprises firms listed under hotel and travels sector in Colombo Stock Exchange (CSE). CSE is the only one share market in Sri Lanka and has 295 companies representing 20 business sectors as at 30th September 2017, with a Market Capitalization of Rs. 2,919.7 Bn. Since the number of hotels and travels companies listed on the main market was only 38 , only 15 companies were selected as sample of this study based on market capitalization.

The study used secondary data that was collected from the published financial statements of the companies available from the web site of Colombo Stock Exchange during the period of 2012 - 2016. The two most important and fundamental characteristics of any measurement procedure are reliability and validity. In this study secondary data was extracted from audited annual report of the listed companies as fairly accurate and reliable. Therefore, these data may be considered as reliable for the study. Necessary checking and cross checking were one while scrutinizing information and data from the secondary sources. Therefore the researcher satisfied with the content and construct validity, then it was decided to continue the analysis.

\subsection{Model specification}

A multiple linear regression model attempts to investigate the influence of audit committee on value relevance of accounting information. The regression was performed by using statistical program Eviews 9. Specifically, the study was operated based on the following research models,

Model I:

$$
\mathrm{EPS}=\beta_{0}+\beta_{1} \mathrm{ACS}+\beta_{2} \mathrm{ACI}+\beta_{3} \mathrm{ACFE}+\beta_{4} \mathrm{ACM}+\beta_{5} \mathrm{FS}+\varepsilon
$$

Model II:

$$
\mathrm{BVPS}=\beta_{0}+\beta_{1} \mathrm{ACS}+\beta_{2} \mathrm{ACI}+\beta_{3} \mathrm{ACFE}+\beta_{4} \mathrm{ACM}+\beta_{5} \mathrm{FS}+\varepsilon
$$

Where:

$\beta_{0,} \beta_{1}, \beta 2 \beta 3, \beta 4, \beta 5$-Regression coefficient

ACS - - Audit committee size

ACI - Audit committee Independence

ACFE - Audit committee Financial Expertise

ACM - Audit committee meetings

FS $\quad-$ Firm size 
E $\quad-$ Error term

\subsection{Operationalisation}

Table 1. Operationalisation of variables

\begin{tabular}{|c|c|c|}
\hline Concept & Variables & Measurement \\
\hline \multirow[t]{4}{*}{ Audit committee } & Audit committee size & Number of audit committee members \\
\hline & $\begin{array}{l}\text { Audit committee } \\
\text { Independence }\end{array}$ & $\begin{array}{l}\text { Proportion of independent directors to } \\
\text { audit committee size }\end{array}$ \\
\hline & $\begin{array}{l}\text { Audit committee Financial } \\
\text { Expertise }\end{array}$ & $\begin{array}{l}\text { Proportion of audit committee members } \\
\text { with financial expertise to the total } \\
\text { number of audit committee members }\end{array}$ \\
\hline & Audit committee meetings & Number of meetings held in financial year \\
\hline \multirow{2}{*}{$\begin{array}{l}\text { Value Relevance of } \\
\text { Accounting } \\
\text { Information }\end{array}$} & Earnings per share & $\begin{array}{l}\text { Net profit after tax divided by number of } \\
\text { outstanding shares }\end{array}$ \\
\hline & Book value per share & $\begin{array}{l}\text { Total stockholder's equity divided by } \\
\text { number of outstanding shares }\end{array}$ \\
\hline Control variable & Firm size & The natural logarithm of total assets \\
\hline
\end{tabular}

\section{Empirical Results}

\subsection{Descriptive Analysis}

Table 02 represents the descriptive statistics of audit committee variables and value relevance of accounting information measured by EPS and BVPS in Sri Lanka during the period of 2012 to 2016.

Table 2. Descriptive Statistics

\begin{tabular}{lccccccc}
\hline & & $\mathrm{AC}_{-}$ & $\mathrm{AC}_{-}$ & $\mathrm{AC}_{-}$ & Firm & & \\
& & independence & Experts & Meetings & Size & EPS & BVPS \\
\hline Mean & 3.000 & 0.777 & 0.916 & 4.183 & 9.246 & 2.632 & 39.597 \\
Median & 3.000 & 0.750 & 1.000 & 4.000 & 9.264 & 1.587 & 26.983 \\
Maximum & 4.000 & 1.000 & 1.000 & 6.000 & 9.874 & 11.587 & 155.137 \\
Minimum & 2.000 & 0.500 & 0.000 & 3.000 & 8.484 & -2.549 & 4.594 \\
Std. Dev. & 0.576 & 0.177 & 0.278 & 0.469 & 0.386 & 3.093 & 36.968 \\
Skewness & -0.021 & 0.153 & -3.015 & 1.571 & -0.494 & 1.341 & 1.512 \\
Kurtosis & 2.716 & 1.675 & 10.090 & 6.177 & 2.462 & 4.706 & 4.897 \\
\hline
\end{tabular}


Table 02 presents the descriptive statistics of all variables employed in this study. On average companies have the audit committee size of 3 . The maximum available audit members on the board in the sample are 4. The standard deviation is only 0.576 (aprox.) audit members. Profile analysis shows that companies have the audit independence of $77 \%$ (aprox) on average. This table also shows that the average audit committee experts of $91.66 \%$ with a standard deviation of 0.278 and has a wide range from 1 to 0 . Audit meeting has the average of 4.183 held per year with the standard deviation of 0.469 . Average firm size is 9.246 with standard deviation of 0.386. Average of EPS and BVPS are 2.632 and 39.597 respectively. There is a highest standard deviation of BVPS and lower audit committee independence.

\subsection{Correlation Analysis}

This study employs a correlation analysis to discover the association and direction of the variables, mainly audit committee and value relevance of accounting information.

Table 3. Correlation Matrix

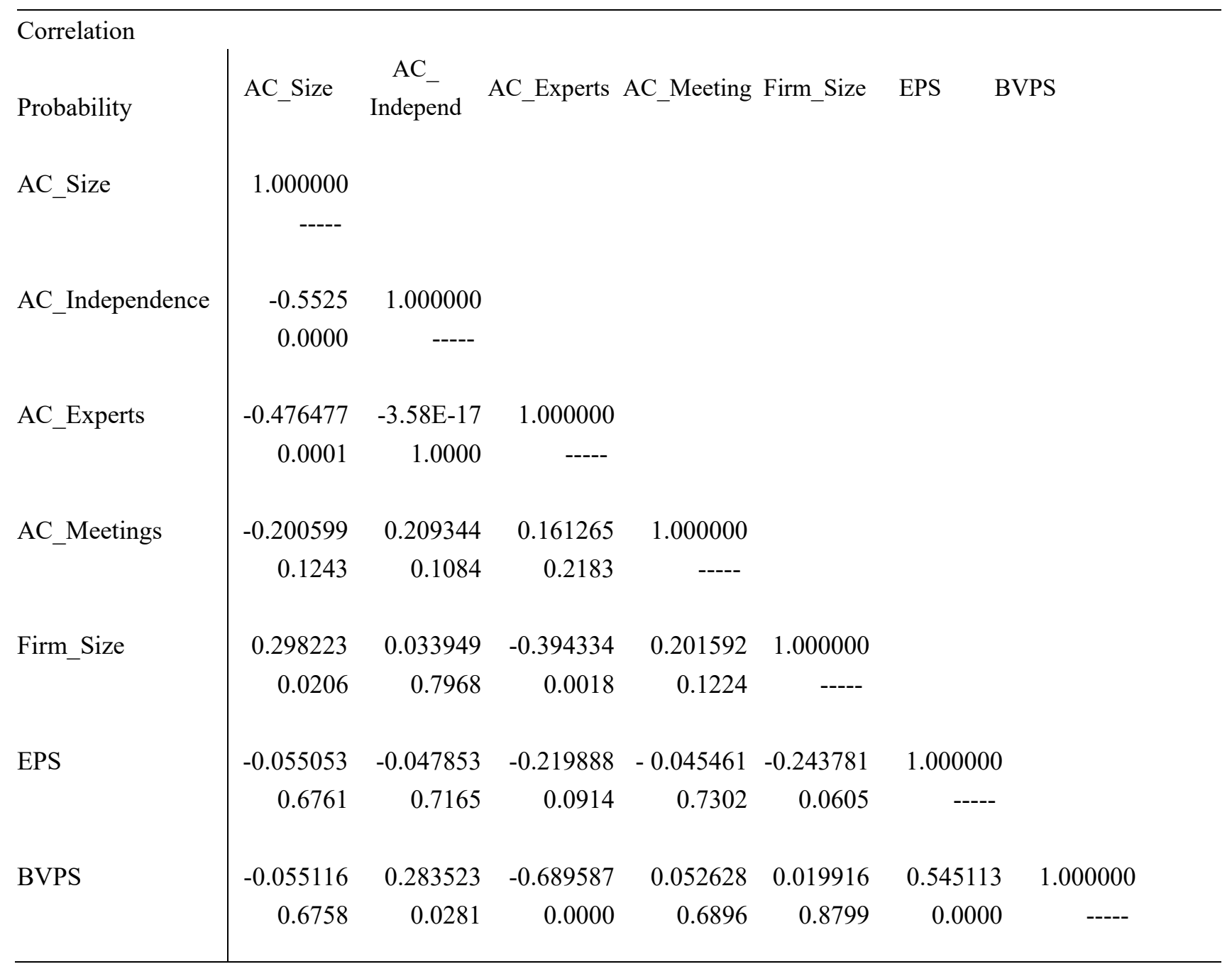

According to the table 03 the value of correlation between audit committee independence and BVPS is 0.283523 which is significant at 0.05 levels; indicates that there is a weak positive association between audit committee independence and BVPS while the value of correlation 
between audit committee experts and BVPS is -0.689587 which is significant at 0.01 levels, represents negative moderate association between audit committee experts and BVPS.

Other audit committees variables such as audit committee size, audit committee meeting and control variable of firm size have an insignificant association with BVPS. Audit committee variables don't have any association with EPS ( $p>0.05)$.

\subsection{Regression Analysis}

In order to examine the impact of audit committee on value relevance of accounting information measured by EPS and BVPS, Least Squares method by using E-views is performed in this study. Results of the analysis are presented in the table 04 and 05.

Table 4. Multiple regression Analysis for EPS

\begin{tabular}{lrcrr}
\hline \multicolumn{1}{c}{ Variable } & Coefficient & Std. Error & t-Statistic & Prob. \\
\hline C & 39.96258 & 10.61069 & 3.766255 & 0.0004 \\
AC_Size & -1.570735 & 0.961126 & -1.634265 & 0.1080 \\
AC_Independence & -3.803871 & 2.732074 & -1.392302 & 0.1695 \\
AC_Experts & -14.59498 & 4.258034 & -3.427634 & 0.0012 \\
AC_Meetings & 0.671838 & 0.856580 & 0.784326 & 0.4363 \\
Firm_Size & -3.010572 & 1.115149 & -2.699704 & 0.0092 \\
& & & & \\
\hline R-squared & 0.228922 & Mean dependent var & & 2.632527 \\
Adjusted R-squared & 0.157526 & S.D. dependent var & & 3.093165 \\
S.E. of regression & 2.839105 & Akaike info criterion & & 5.019494 \\
Sum squared resid & 435.2678 & Schwarz criterion & 5.228928 \\
Log likelihood & -144.5848 & Hannan-Quinn criter. & 5.101415 \\
F-statistic & 3.206364 & Durbin-Watson stat & & 0.884716 \\
Prob(F-statistic) & 0.013174 & & \\
\hline
\end{tabular}

According to the table 04, coefficient of determination for audit committee variables $\left(\mathrm{R}^{2}\right)$ is 0.228922 which denotes that $22.89 \%$ of the observed variability in EPS can be explained by the differences in the variables such as audit committee size, audit committee independence, audit committee experts, audit committee meetings and firm size. The remaining $77.11 \%$ of the variances is related to the other variables which are not depicted in this model. In this analysis, $F$ statistic is $3.206364, p<0.05$, indicated that the model is significant. It means that the regression results are acceptable for this analysis and all variables (audit committee size, audit committee independence, audit committee experts, audit committee meeting and firm size) jointly in the model significantly affect the EPS at 5\% significant levels.

Among the all four audit committee variables considered in the analysis, only one audit committee variable has a significant impact on EPS. Audit committee experts has a significant negative influences on EPS $(B=-14.59498, p<0.05)$, similar pattern is observed in firm size that has a significant negative impact on value relevance of accounting information 
$(B=-3.010572, p<0.05)$. Further audit committee variables such as Ac size, AC independence and $\mathrm{AC}$ meetings have no significant impact on EPS.

Table 5. Multiple regression Analysis for BVPS

\begin{tabular}{lrcrr}
\hline \multicolumn{1}{c}{ Variable } & Coefficient & Std. Error & t-Statistic & Prob. \\
\hline C & 426.1849 & 72.61375 & 5.869204 & 0.0000 \\
AC_Size & -25.45047 & 6.577417 & -3.869371 & 0.0003 \\
AC_Independence & 7.086670 & 18.69681 & 0.379031 & 0.7062 \\
AC_Experts & -343.3952 & 29.13964 & -11.78447 & 0.0000 \\
AC_Meetings & 15.33787 & 5.861959 & 2.616510 & 0.0115 \\
Firm_Size & -29.54916 & 7.631465 & -3.872016 & 0.0003 \\
\hline R-squared & 0.747190 & Mean dependent var & 39.59759 \\
Adjusted R-squared & 0.723781 & S.D. dependent var & 36.96833 \\
S.E. of regression & 19.42927 & Akaike info criterion & 8.866078 \\
Sum squared resid & 20384.81 & Schwarz criterion & 9.075512 \\
Log likelihood & -259.9823 & Hannan-Quinn criter. & 8.947999 \\
F-statistic & 31.91975 & Durbin-Watson stat & 0.308415 \\
Prob(F-statistic) & 0.000000 & &
\end{tabular}

According to the table 05 , coefficient of determination for audit committee variables $\left(\mathrm{R}^{2}\right)$ is 0.747190 which denotes that $74.71 \%$ of the observed variability in BVPS can be explained by the differences in the variables such as audit committee size, audit committee independence, audit committee experts, audit committee meeting and firm size. The remaining $25.29 \%$ of the variances is related to the other variables which are not depicted in this model. In this analysis, F statistic is $31.91975, \mathrm{p}<0.05$, indicated that the model is significant. It means that the regression results are acceptable for this analysis and all variables (audit committee size, audit committee independence, audit committee experts, audit committee meetings and firm size) jointly in the model significantly affect the BVPS at $5 \%$ significant levels.

Among the all four audit committee variables considered in the analysis, only three audit committee variables have a significant impact on BVPS which are audit committee size, audit committee experts and audit committee meeting. Audit committee size has a significant negative influences on BVPS $(B=-25.45047, p<0.05)$, similar pattern is observed in audit committee experts that has a significant negative impact on BVPS $(B=-343.3952, p<0.05)$. Further audit committee meetings has a significant positive influences on BVPS $(\mathrm{B}=$ 15.33787, $\mathrm{p}<0.05)$. Firm size has a significant negative influences on BVPS $(B=-29.54916$, $\mathrm{p}<0.05)$. The coefficient of audit committee independence shows that audit committee 
independence has no significant impact on BVPS.

By using the multiple regression analysis the hypotheses are examined in this study. Hypothesis $\left(\mathrm{H}_{1}\right)$ stated that audit committee size significantly influences value relevance of accounting information measured by EPS and BVPS. According to the table 04 and table 05 , there isn't a significantly impact of AC size on EPS ( $p=0.1080>0.05)$ and AC size has a significant influence on BVPS $(\mathrm{p}=0.0003<0.05)$ as a result $\mathrm{H}_{1}$ is supported in terms of BVPS.

Hypothesis $\left(\mathrm{H}_{2}\right)$ stated that audit committee independence significantly influences value relevance of accounting information. According to the table 04 and table 05, there isn't a significantly impact of Ac independence on value relevance of accounting information measured by EPS $(p=0.1695>0.05)$ and BVPS $(p=0.7062>0.05)$, as a result $\mathrm{H}_{2}$ is not supported.

Hypothesis $\left(\mathrm{H}_{3}\right)$ states that audit committee experts significantly influences value relevance of accounting information. According to the table 04 and table 05 there is a significant negative impact of audit committee experts on value relevance of accounting information measured by EPS $(p=0.0012<0.05)$ and BVPS $\left(p=0.00<0.05\right.$, as a result $\mathrm{H}_{3}$ is supported.

Hypothesis $\left(\mathrm{H}_{4}\right)$ stated that audit committee meetings significantly influence value relevance of accounting information measured by EPS and BVPS. According to the table 04 and table 05 , there isn't a significantly impact of AC meetings on EPS $(\mathrm{p}=0.4363>0.05)$ and AC meetings has a significant influence on BVPS $(\mathrm{p}=0.0115<0.05)$ as a result $\mathrm{H}_{4}$ is supported in terms of BVPS.

\section{Conclusion}

The overall goal of this study is to investigate the impact of various $\mathrm{AC}$ attributes, such as the $\mathrm{AC}$ size, $\mathrm{AC}$ independence, $\mathrm{AC}$ expertise and $\mathrm{AC}$ meetings on the value relevance of accounting information measured by EPS and BVPS for the listed hotels and travels. Audit committee attributes such as AC size, AC experts and AC meetings have a significant impact on BVPS of listed hotels and travels in Sri Lanka. Further, AC experts significantly influence the EPS. The results of the study suggest that the features of audit committees in Sri Lanka are relevant with value relevance of accounting information in terms of BVPS.

The findings could be useful to regulators in other jurisdiction who are looking at ways to enhance the effectiveness of AC, overall firm governance and enhance investors' confidence in the firms. Future studies could examine other committee attributes such as size, individual characteristics of the directors on the committee and the internal processes of the committee. Furthermore, the study used secondary data; future studies could use primary data or a combination of primary and secondary data. Finally, future studies could consider taking a qualitative approach to examine the impact of $\mathrm{AC}$ attributes on value relevance of accounting information.

\section{References}

Abbott, L.J., Park, Y., \& Parker, S. (2000). The effects of audit committee activity and 
independence on corporate fraud. Managerial Finance, 26, 55-67. https://doi.org/10.1108/03074350010766990

Abbott, L.J., Parker, S., \& Peters, G.F. (2004). Audit committee characteristics and restatements. Auditing: A Journal of Practice and Theory, 23(1), 69-87. https://doi.org/10.2308/aud.2004.23.1.69

Beisland, L.A. (2009). A Review of the Value Relevance Literature. The Open Business Journal, 02, 07-27. https://doi.org/10.2174/1874915100902010007

Ball, R., \& Brown, P. (1968). An empirical evaluation of accounting income numbers. Journal of Accounting Research, 6, 159-78. https://doi.org/10.2307/2490232

Carcello, J. V., \& Neal, T. L. (2003). Audit committee characteristics and auditor dismissals following "new" going-concern reports. The Accounting Review, 78(1), 95-117. https://doi.org/10.2308/accr.2003.78.1.95

Carcello, J.V., Neal, T.L., Palmrose, Z.-V., \& Scholz, S. (2011). CEO involvement in selecting board members, audit committee effectiveness, and restatements. Contemporary Accounting Research, 28(2), 396-430. https://doi.org/10.1111/j.1911-3846.2010.01052.x

Charan, R. (1998). How Corporate Boards Create Competitive Advantage. Jossey-Bass, San Francisco, CA.

Craven, K.S., \& Wallace, W.A. (2001). A framework for determining the influence of the corporate board of directors in accounting studies. Corporate Governance, 9(1), 2-23. https://doi.org/10.1111/1467-8683.00222

Davidson, W.N., Xie, B., \& Xu, W. (2004). Market reaction to voluntary announcement of audit committee appointments: the effect of financial expertsise. Journal of Accounting and Public Policy, 23(4), 279-293. https://doi.org/10.1016/j.jaccpubpol.2004.06.001

DeZoort, F.T. \& Salterio, S.E. (2001). The effects of corporate governance experience and financial reporting and audit knowledge on audit committee directors' judgments. Auditing: A Journal of Practice \& Theory, 20, 31-48. https://doi.org/10.2308/aud.2001.20.2.31

Felo, A.J., Krishnamurthy, S., \& Solieri, S. A. (2003). Audit committee characteristics and the perceived quality of financial reporting: an empirical analysis. https://doi.org/10.2139/ssrn.401240.

Graham,B., Dodd,D.L., \& Cottle,S. (1962). Security Analysis, 4 ${ }^{\text {th }}$ ed., McGraw Hill, NewYork, NY.

Klein, April (2002). Audit Committee, Board of Director Characteristics, and Earnings Management. Journal of Accounting and Economics, 33(3), 375-400. https://doi.org/10.1016/S0165-4101(02)00059-9

Kalbers, L. P., \& Fogarty, T. J. (1993). Audit committee effectiveness: An empirical investigation of the contribution of power. Auditing: A Journal of Practice and Theory, 12(1), 24-49. 


\section{Al Macrothink}

Asian Journal of Finance \& Accounting

ISSN 1946-052X

2017, Vol. 9, No. 2

Miller, M., \& Modigliani, F. (1961). Dividend policy, growth and the valuation of shares. Journal of Business, 34(4), 411-33. https://doi.org/10.1086/294442

OECD. (2003). White paper on corporate governance in Asia. Asian roundtable on corporate governance.

Ohlson, J.A. (1995). Earnings, book values and dividends in security valuation. Contemporary Accounting Research, 11, 661-88. https://doi.org/10.1111/j.1911-3846.1995.tb00461.x

Porter, B. \&P. Gendall. (1993). An International Comparison of the Development and Role of Audit Committees in the Private Corporate Sector. Paper presented at European Accounting Association Conference, Turku, Finland.

Ruzaidah, R., \& Takiah, M.I. (2004). "The effectiveness of audit committee in monitoring the quality of corporate governance", Corporate Governance: An International Perspective, Malaysian Institute of Corporate Governance, Kuala Lumpur, pp. 154-75.

Senaratne, S. (2007). Level of Informativeness of Annual Reports and Corporate Governance: A Study of Sri Lankan Quoted Public Companies. Doctoral Thesis, University of Colombo.

Senaratne, S., \& Gunaratne, P. S. M. (2007). Significant features and associated issues of corporate governance practices of Sri Lankan listed companies. Proceedings from International Research Conference on Knowledge for Growth and Development. Faculty of Management and Finance, University of Colombo, Sri Lanka.

Teoh, H.Y., \& Lim, C. (1996). An Empirical Study of the Effects of Audit Committees, Disclosure of Non audit Fees and Other Issues on Audit Independence: Malaysian Evidence. Journal of International Accounting, Auditing and Taxation, 5(2), 231-248. https://doi.org/10.1016/S1061-9518(96)90007-5

Wathne, K.H., \& Heide, J.B. (2000). Opportunism in inter-firm relationship: forms, outcomes and solutions. Journal of Marketing, 64(4), 36-51. https://doi.org/10.1509/jmkg.64.4.36.18070

Watts, R.L., \& Zimmerman, J. (1986), Positive Accounting Theory, Prentice-Hall, EnglewoodCliffs, NJ. 